\title{
Ecotoxicological research and related legislation in Serbia
}

\author{
Ivana Teodorović
}

Received: 23 March 2009 /Accepted: 31 March 2009/Published online: 30 April 2009

(C) Springer-Verlag 2009

\begin{abstract}
Introduction Several hot spots of severe freshwater pollution and sediment contamination (mostly heavy metals, polyaromatic hydrocarbons and polychlorinated biphenyls) have been identified in Serbia as the consequence of outdated environmental legislation, negligible amounts of properly treated waste waters and accidental spills.

Discussion Since ecotoxicological methods have never been incorporated into risk assessment procedures, mandatory effluent discharge or ambient water monitoring programmes, ecotoxicological research, based on bioaccumulation studies, conventional ecotoxicological tests and, recently, biomarkers of exposure and effect have been restricted to independent smallto medium-scale studies, conducted, basically, to confirm, underline or oppose the results of chemical-based monitoring and to lament on inadequate environmental regulations/policy and management practice. Although hot and unresolved ecotoxicological problems still remain beyond the reach of ecotoxicological research currently conducted in Serbia, or are tackled only sporadically, it is to be expected that on-going research and institutional capacity building should, hopefully, increase the competence and competitiveness of scientific community and speed up the process of harmonisation of national environmental legislation and policy with European Union.
\end{abstract}

Responsible editor: Walter Giger

Ivana Teodorović is President of the International Association for Danube Research (IAD) http://www.iad.gs.

ESPR Special Issue - ESTROM

I. Teodorović $(\bowtie)$

Laboratory of Ecotoxicology (LECOTOX),

Department of Biology and Ecology, Faculty of Sciences,

University of Novi Sad,

Trg Dositeja Obradovića 2,

21000 Novi Sad, Serbia

e-mail: teodorovic@beocity.net

URL: http://www.lecotox.net
Keywords Biomarkers · Contaminated sediments · Danube River Basin · Ecotoxicological testing . Hazardous substances · Legislation · Research · Risk assessment

\section{Background, aims and scopes}

As a signatory party of The Danube River Protection Convention and a contracting party of International Commission for the Protection of the Danube River (ICPDR) since August 2003, Serbia has been committed to implementation of the Danube Convention, the objectives of which, amongst others, include the control of hazards originating from accidents involving hazardous substances and implementation of measures to reduce pollution loads entering the Black Sea from sources in the Danube River Basin. Since ICPDR got the mandate for implementation of the European Union (EU) Water Framework Directive (WFD), Serbia, although not an EU Member State yet, has been undertaking measures to contribute to fulfilment of the WFD main objective - good ecological status of all European rivers by 2015.

This review aims at presenting a comprehensive overview of recent and contemporary ecotoxicological research in Serbia. One of the objectives of this paper is to put the fundamental and applied research and the results obtained over the last decade into the context of historical and social-economic conditions, along with the current environmental legislation, in order to search for the reasons for relatively modest interest in ecotoxicology within the Serbian research community and almost complete absence of interest amongst water managers and competent authorities. In the end, perspectives and possible future trends in ecotoxicological research in Serbia will be stressed. 


\section{Main features}

The review is based on the peer-reviewed articles that have been published in international journals and available official reports that have been published by the competent authorities in the region.

\section{Results}

3.1 Current Serbian environmental regulations related to water protection and hazardous substances

For years, Serbian environmental legislation has been (and it still is) an ambient-standard based: Common national emission level values have never existed, so the regulations have been developed to ensure that the discharge does not violate numeric ambient standards and narrative criteria outside the mixing zone. Compliance monitoring exclusively includes water quality assessment based on physicochemical parameters, while whole effluent toxicity testing (WET) is not required by any environmental regulations in Serbia. Industrial waste waters are customarily discharged (partly treated or untreated) into sewage systems, or directly into receiving waters. Yet, according to recent estimates (SWRDMP 2002), less that $10 \%$ of all waste waters generated in Serbia are treated at all, which means that effluents still present an actual hazard to aquatic environment. Oddly enough, official surface water quality monitoring programmes have relied for years mostly on physicochemical water quality parameters and to some extent on biomonitoring data (saprobic indices based on plankton communities). Ambient standards, which are rather outdated nowadays, are set for water column only, while sediment quality criteria have never been established so far. Also, ambient water and sediment toxicity evaluation have never been included into official monitoring programmes.

Important environmental laws adopted in 2004 should, eventually, enable transposition of the Environmental Impact Assessment, Strategic Environmental Assessment and Integrated Pollution Prevention and Control Directives, provided that the missing secondary legislation, i.e. bylaws (emission level values in the first place) is adopted soon enough. A new Water Law (harmonised with the WFD) and accompanying bylaws, the Law on Biocides and Law on Chemicals, are in preparation. Serbia received the contribution from the Swedish International Development Cooperation Agency for the implementation of the Project "Chemicals Risk Management in Serbia 2007-2010" as a step towards the harmonisation and approximation of national legislation with EU Registration, Evaluation, Authorisation and Restriction of Chemicals (REACH) Directive.
3.2 Water quality monitoring programmes and the current state of the aquatic environment in Serbia with respect of contamination with hazardous substances

The Republic Hydro Meteorological Service is the competent authority in charge of official water quality monitoring in the Republic of Serbia. The daily, weekly and annual reports, as well as sampling station network and a list of water quality parameters (with environmental standards and criteria) are available for public download (http://www. hidmet.gov.rs/eng/zivotnasredina/index.php). Serbia is also a part of Danube Trans-National Monitoring Networkannual reports are available at ICPDR official web site http://www.icpdr.org.

Official monitoring programmes and independent studies performed recently (UNEP 2004; ICPDR 2005 IvančevTumbas et al. 2004, 2008; Terzić et al. 2008; Sakan et al. 2007) identified several hot spots of severe freshwater pollution and soil and sediment contamination that are attributed to outdated environmental policy, regulations and management practice, heavy pollution caused by insufficient wastewater treatment as well as major accidental spills (as the result of North Atlantic Treaty Organisation (NATO) campaign in 1999, or Baya Mare cyanide accident in 2000, for instance). They include certain sections of the DanubeTisa-Danube Hydrosystem canal network (the biggest canal network in the Danube River Basin), Iron Gate Reservoirs and the Tisa River sediments. Heavy metals appear as the most emphasised problem, although the elevated contents of organic pollutants (polychlorinated biphenyls (PCBs), organochlorine pesticides, polyaromatic hydrocarbons (PAHs), organic micro pollutants, even emerging substances) have also been registered in some areas. Yet, the obvious lack of knowledge on organic xenobiotics (sources, fluxes, environmental fate and risks) should be stressed. The largest individual hot spot is the industrial complex near the city of Pančevo-effluents are discharged into the wastewater canal entering the River Danube (Jovančević et al. 2005). Many reservoirs in the central part of Serbia encounter the problem of contaminated sediments (Ivančev-Tumbas et al. 2004), while the south of the country, which was affected by the NATO campaign, has been recognised as a hot spot of depleted uranium contamination (Radenković et al. 2008).

3.3 Recent and contemporary ecotoxicological research in Serbia

\subsubsection{Laboratory scale ecotoxicological research}

Studies on relative sensitivity of standard test species and/or endpoints to various toxic substances, as well as studies on effects of priority pollutants, began in the late 1970s, with pioneer studies of effects of heavy metals on survival and 
respiration rate of tubificid worms (Brković-Popović and Popović 1977a, b), Daphnia magna (Brković-Popović 1990), acute toxicity of heavy metals and phenols to Allium cepa, Lepidium sativum and D. magna (Arambašić et al. 1995) and, recently, study on impact of culturing patterns on chronic toxicity testing with D. magna (Teodorović and Planojević 2008). The initial steps in application of histological, biochemical and physiological biomarkers in laboratory scale ecotoxicological research, mainly in laboratory studies on modes of toxic effects of heavy metals and certain pesticides on aquatic species, date back to the 1990 s. These include the study on activities of superoxide dismutase (SOD) and catalase (CAT) in erythrocytes and transaminases in the plasma of carps and goldfish exposed to cadmium (Žikić et al. 1997, 2001), study on acute and sub-acute toxicity of atrazine and 2,4-D herbicide to carp (Nešković et al. 1993, 1994); research on functional enzymes activity and gill histology of carp after glyphosate, copper sulphate and trifluralin exposure and recovery (Nešković et al 1996; Karan et al. 1998; Poleksić and Karan 1999). The results of all cited studies on effects of pesticides to carp, as well as previously mentioned studies on toxicity of metals to D. magna, are included into the ECOTOX database (http:// cfpub.epa.gov/ecotox/ecotox_home.cfm).

\subsubsection{Ecotoxicology in environmental monitoring}

The lack of reliable ecotoxicological data due to rather conservative official monitoring programmes based on traditional set of physicochemical parameters stimulated the implementation of small to regional scale field ecotoxicological research projects that are based on (a) bioaccumulation studies, mostly on heavy metals in fish (Teodorović et al. 2000) or mosses and lichen (Popović et al. 2008) and PCBs in aquatic biota (Adamov et al. 2003) and (b) conventional ecotoxicological tests, such as the study on chronic toxicity of the Sava River (water and sediment), based on algal bioassay (Kallqvist et al. 2008). Sediment toxicity evaluations, undertaken as a part of feasibility studies for remediation activities on transboundary watercourses (Dalmacija et al. 2006; Prica et al. 2008), showed that although heavy metal concentrations were high, bioavailability and consequently toxicity to aquatic biota was low, due to the high content of clay, iron and sulphides (Table 1). The study on the relationship between WET and mandatory effluent monitoring across a range of industry types (Teodorović et al. 2009) showed that even effluents fulfilling discharge requirements are quite often moderately to highly toxic (Fig. 1).

Non-conventional tests and modern effect directed analyses (EDA) approach are being gradually applied, as evidenced by the sediment contact test with Myriophyllum aquaticum and Lemna sp. applied to assess the sediment quality (Stešević et al. 2007), application of Vibrio fischeri Flesh test in the search for the optimum test battery for assessment of contaminated sediments (Planojević et al. 2008) and EDA approach in contaminated sediments of Pancevo hot spot (Kaišarević et al. 2008). Biomarkers of exposure and effect are also being applied of late, e.g. the study on effects of acute cyanide poisoning on the fish gills
Table 1 Parameters determining bioavailability/toxicity of metals in the sediment of the Begej Canal (Vojvodina, Serbia; from Dalmacija et al. 2006, with permission): The ratio $\Sigma[\mathrm{SEM}] /[\mathrm{AVS}]>1$ was recorded at several locations that were already recognised as places of high risk based on Dutch standards

\begin{tabular}{|c|c|c|c|c|c|c|c|c|c|c|c|}
\hline \multirow[t]{2}{*}{ Sample } & \multicolumn{5}{|l|}{$\left[\mathrm{SEM}_{i}\right] / R / \%$} & \multirow[t]{2}{*}{ [AVS] } & \multirow[t]{2}{*}{$\Sigma\left[\mathrm{SEM}_{i}\right]$} & \multirow[t]{2}{*}{$R_{1}$} & \multirow[t]{2}{*}{$R_{2}$} & \multirow[t]{2}{*}{$R_{3}$} & \multirow[t]{2}{*}{$R_{4}$} \\
\hline & $\mathrm{Ni}$ & $\mathrm{Cd}$ & $\mathrm{Zn}$ & $\mathrm{Pb}$ & $\mathrm{Cu}$ & & & & & & \\
\hline 1 (top) & $0.05 / 0.01 / 4.5$ & $0.08 / 0.02 / 40$ & $6.6 / 1.8 / 55$ & $0.05 / 0.01 / 6.1$ & $1.05 / 0.3 / 35$ & 3.73 & 7.83 & 2.1 & 4.1 & 115 & 3.02 \\
\hline 1 (bottom) & $0.06 / 0.02 / 7.5$ & $0.03 / 0.01 / 32$ & $4.0 / 1.2 / 42$ & $0.07 / 0.02 / 5.8$ & $0.94 / 0.3 / 27$ & 3.42 & 5.13 & 1.5 & 1.7 & 110 & 2.77 \\
\hline 4 (top) & $0.03 / 0.01 / 5.0$ & $0.004 / 0.001 / 20$ & $1.6 / 0.5 / 30$ & $0.03 / 0.01 / 2.9$ & $1.1 / 0.3 / 33$ & 3.45 & 2.76 & 0.8 & $<0$ & 82.9 & 1.69 \\
\hline 6 (top) & $0.03 / 0.01 / 3.0$ & $0.06 / 0.01 / 20$ & $2.2 / 0.5 / 20$ & $0.04 / 0.01 / 4.9$ & $0.56 / 0.1 / 20$ & 4.13 & 2.89 & 0.7 & $<0$ & 86.7 & 1.8 \\
\hline 6 (bottom) & $0.08 / 0.04 / 13$ & $0.001 / 0.0007 / 18$ & $0.71 / 0.3 / 42$ & $0.07 / 0.003 / 5.5$ & $0.21 / 0.1 / 30$ & 4.18 & 1.01 & 0.2 & $<0$ & 266 & 5.67 \\
\hline 9 (top) & $0.14 / 0.02 / 8.4$ & $0.21 / 0.03 / 35$ & $9.4 / 1.2 / 47$ & $0.02 / 0.002 / 1.4$ & $1.59 / 0.2 / 30$ & 7.57 & 11.36 & 1.5 & 3.79 & 66.2 & 1.42 \\
\hline 9 (bottom) & $0.08 / 0.02 / 5.6$ & $0.16 / 0.04 / 38$ & $3.74 / 1.01 / 33$ & $0.08 / 0.02 / 5.7$ & $0.77 / 0.2 / 22$ & 7.71 & 4.83 & 0.6 & $<0$ & 125 & 1.72 \\
\hline 13 (top) & $0.07 / 0.01 / 4.5$ & $0.15 / 0.02 / 32$ & $6.29 / 0.94 / 3.0$ & $0.07 / 0.01 / 6.0$ & $1.48 / 0.22 / 38$ & 6.72 & 8.06 & 1.2 & 1.34 & 82.3 & 0.81 \\
\hline 13 (bottom) & $0.01 / 0.002 / 1.0$ & $0.037 / 0.008 / 34$ & $4.7 / 1.02 / 42$ & $0.36 / 0.08 / 11$ & $1.37 / 0.3 / 28$ & 6.83 & 6.48 & 0.9 & $<0$ & 92.9 & 1.57 \\
\hline 14 (top) & $0.02 / 0.02 / 3.5$ & $0.003 / 0.003 / 26$ & $0.33 / 0.3 / 22$ & $0.002 / 0.0002 / 1.0$ & $0.08 / 0.08 / 17$ & 1.10 & 0.44 & 0.4 & $<0$ & 260 & 13 \\
\hline
\end{tabular}

The other samples have the ratios $\Sigma[\mathrm{SEM}] /[\mathrm{AVS}]<1$, despite the high class based on the Dutch evaluation. A low ratio of $\left[\mathrm{SEM}{ }_{i}\right]$ to the corresponding total average concentration $(<55 \%)$ might indicate that metals are bound to a relatively inert phase and point out to a limited bioavailability. $\left[\mathrm{SEM}_{i}\right]\left(\mu \mathrm{mol} \mathrm{g}{ }^{-1}\right) ; R=\left[\mathrm{SEM}_{i}\right] /[\mathrm{AVS}] ; \%$ - percentage of $\left[\mathrm{SEM}_{i}\right]$ to the total concentration of $i$ th metal in the sediment; [AVS] $\left(\mu \mathrm{mol} \mathrm{g}{ }^{-1}\right) ; \Sigma\left[\mathrm{SEM}_{i}\right]=\operatorname{SEM}(\mathrm{Cd})+\operatorname{SEM}(\mathrm{Cu})+\operatorname{SEM}(\mathrm{Ni})+\mathrm{SEM}(\mathrm{Pb})+\operatorname{SEM}(\mathrm{Zn})\left(\mu \mathrm{mol} \mathrm{g}^{-1}\right) ; R_{1}=\Sigma\left[\mathrm{SEM}_{i}\right] /[\mathrm{AVS}] ; R_{2}=\Sigma\left[\mathrm{SEM}_{i}\right]-[\mathrm{AVS}] ;$ $R_{3}=[\mathrm{Fe}] /[\mathrm{AVS}]$ and $R_{4}=[\mathrm{Mn}] /[\mathrm{AVS}]$ 


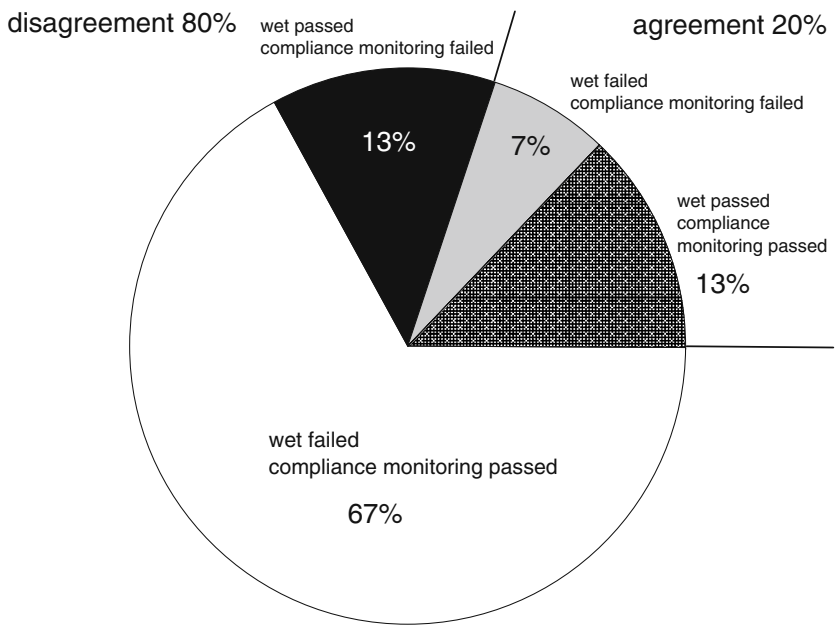

Fig. 1 Percentage of agreement between the whole effluent toxicity test and the chemical characterisation based on compliance monitoring (from Teodorović et al. 2009, with permission)

(Poleksić and Jeremić 2003), genotoxicity screening of the river Rasina in Serbia based on Allium anaphase-telophase test (Vujošević et al. 2008), assessment of pollution in the Danube River near Novi Sad based on several biomarkers (SOD, catalase, glutathione peroxidase (GSH-Px), glutathione S-transferase (GST), induction of CYP1A1 in liver) in sterlet (Stanić et al. 2006) and the study on antioxidant defence enzyme activities (SOD, CAT, GSH-Px, glutathione reductase, GST) in hepatopancreas, gills and muscle of Spiny cheek crayfish from the River Danube (Borković et al. 2008). Although the applied biomarkers are rather unspecific, the toxicity identification evaluation is missing in all the mentioned studies, so stress confirmed by the results could not be attributed to a specific group of toxic substances. Toxicity of samples from Kragujevac hot spot (Zorić et al. 2004) and soil from oil refineries in Vojvodina (after the NATO campaign spills; Kaišarević et al. 2007), determined by micro-ethoxyresorufin-o-deethylase analysis, could not be attributed exclusively to the contents of measured PCBs and PAHs (Table 2), but they should be attributed also to the presence of unknown dioxin-like compounds, and/or positive interactions among similarly acting chemicals, proving that biotests, when applied in ecotoxicological assessments, should be used as a screening tool or initial step in effect-directed analyses.

\subsubsection{Recent and on-going national, regional and international research projects in the field of ecotoxicology}

A recent turbulent history and a period of sanctions during the 1990s lead to severe isolation of Serbia from the rest of the world, over a long period of time. Research institutions and individual scientists were not eligible for participation in international projects so that cooperation between the
Serbian research community and the rest of the world was kept on a personal basis. The research was supported only by national funding mechanisms which, due to a rather limited capacity, proved to be insufficient to keep pace with contemporary research. However, Serbian researchers and institutions have recently become eligible partners to the EU Framework Programme (FP) and other EU funding programmes. A big step forward related to ecotoxicological research was reflected, for instance, in participation of the University of Novi Sad, Faculty of Sciences in the APOPSBAL project (Assessment of the selected POPs (PCBs, PCDD/Fs, POCPs) in the Atmosphere and Water Ecosystems from Waste Materials Generated by Warfare in the Area of Former Yugoslavia, FP5-ICA2-CT-2002-10007, 2002-2005). Still, Serbian research institutions are not included in any of the major, recent and on-going EUfunded ecotoxicological projects (e.g. Modelkey-http:// www.modelkey.org; AquaTerra-http://www.attemptoprojects.de/aquaterra/; Liberation-http://www.liberation. dk/; NoMiracle—http://nomiracle.jrc.ec.europa.eu). During the last couple of years, a significant number of research laboratories in Serbia have been upgraded with state-of-theart laboratory equipment, quality training in and networking with the respectful European research centres via the National Investment Fund of Serbia, regional programmes (e.g. biomarkers of exposure and of effects of persistent

Table 2 Bio-TEQ values (pg PCB126/g d.w.), PCB and PAH levels (ng/g d.w.) in soil samples from Oil Refinery Novi Sad (from Kaišarević et al. 2007, with permission)

\begin{tabular}{|c|c|c|c|c|}
\hline \multirow[t]{2}{*}{ Sample } & \multicolumn{2}{|c|}{ Refined hexane extract } & \multicolumn{2}{|c|}{ PAH fraction } \\
\hline & Bio-TEQ $^{\mathrm{a}}$ & $\Sigma \mathrm{PCBs}^{\mathrm{b}}$ & Bio-TEQ $^{\mathrm{a}}$ & $\Sigma \mathrm{PAHs} \mathrm{s}^{\mathrm{c}}$ \\
\hline NS 1 & 13.72 & 1.47 & NA & NA \\
\hline NS 2 & 241.22 & 0.94 & 742.30 & 175.9 \\
\hline NS 3 & 76.99 & 4.95 & NA & NA \\
\hline NS 4 & 444.97 & 581.44 & 924.72 & $3,928.6$ \\
\hline NS 5 & 224.74 & 0.55 & NA & NA \\
\hline NS 6 & 911.22 & $<0.05$ & $18,701.49$ & 507.1 \\
\hline NS 7 & 127.18 & 1.84 & NA & NA \\
\hline NS 8 & 15.22 & 1.48 & 425.47 & $<5$ \\
\hline NS 9 & 235.74 & 18.14 & 244.54 & $<5$ \\
\hline NS 10 & 25.70 & 1.93 & 47.31 & $<5$ \\
\hline
\end{tabular}

NA sample was not analysed on the presence of PAHs and corresponding bio-TEQ value

${ }^{\mathrm{a}}$ Bio-TEQ $=$ PCB126EC25/SampleEC25PCB126

${ }^{\mathrm{b}}$ Riedel-de-Haen standard of seven PCB congener nos. 28, 52, 101, 138, 153, 180 and 209

${ }^{\mathrm{c}}$ Standard mixture of 16 components: acenaphthene, acenaphthylene, anthracene, benzo(a)anthracene, benzo(a)pyrene, benzo(b)fluoranthene, benzo(g,h,i)perylene, benzo(k)fluoranthene, chrysene, dibenzo(a,h)anthracene, fluoranthene, fluorene, indeno( $1,2,3,-$ cd $)$ pyrene, naphthalene, phenanthrene and pyrene 
organic pollutants in ecosystem, WUS Austria 87/2002, 2002-2005 granted to the University of Novi Sad, Faculty of Sciences) and FP INCO special programmes for Western Balkan countries (e.g. two on-going projects at the University of Novi Sad, Faculty of Sciences: Reinforcement of Research Potential of the Laboratory for Ecotoxicology (REP-LECOTOX), INCO-CT-2006-043559-REP-LECOTOX (http://www.lecotox.net) and Reinforcement of the Laboratory for Environmental Protection as a Centre of Excellence for Environmental Chemistry and Risk Assessment (CECRA), INCO-CT-2006-043741 (http://www.cecra. ih.ns.ac.yu)).

\section{Discussion}

As has been previously stated, quite a large number of the so-called hot spots of extreme water pollution (sediments in particular) and soil contamination have been identified over the past decade in Serbia. Consequently, it could be expected that ecotoxicology as a discipline stands rather high in the agenda of researchers, professionals and funding agencies in Serbia. However, ecotoxicological methods have never been incorporated into risk assessment, or mandatory effluent and official ambient water monitoring programmes, nor have they been applied in environmental quality standards setting. Therefore, the research has been restricted for years on small- to medium-scale laboratory and monitoring-like studies, rare fundamental and sporadic conceptual research, which mainly applied conventional ecotoxicological methods and standard aquatic test species and which have been undertaken by a few independent research teams. Moreover, the results until the mid-1990s either remained unpublished or ended up in the so-called grey literature. Only recently, Serbian researchers have begun publishing the results of their studies in international peer-reviewed, yet low- to medium-ranked, journals, but majority of articles still belong to rather descriptive reportlike papers. The results that have been published are derived from the modestly funded studies where wellestablished standardised ecotoxicological methods are applied, basically, to confirm, underline or oppose the results of chemical-based monitoring and to lament on inadequate environmental regulations/policy and management practice. Proper scientific research and unresolved ecotoxicological problems still remain beyond the reach of ecotoxicological research currently conducted in Serbia, or they are tackled only sporadically. They are dealing mainly with (a) the contribution of individual toxicants to overall toxicity of the complex mixtures; (b) the interaction between potentially present toxicants and other compounds in complex matrices and, consequently, the bioavailability of toxicants; (c) the problem of toxicity identification evaluation in complex mixtures; (d) extrapolation from laboratory (or species) to ecosystem scale and (e) development of alternative methods and endpoints, including the application of genomic-based tools, which would be more sensitive to priority pollutants and emerging substances.

\section{Conclusions}

Environmental protection in Serbia has been standing rather low on the agenda of policy and decision makers for many years now, due to numerous historic and social-economic factors. The outdated environmental legislation and poor implementation, insufficient waste water treatment, ineffective environmental monitoring programmes, limited human resources and absence of knowledge on risk assessment of hazardous substances have characterised water protection and management sector for years. Such under-prioritisation of serious environmental problems led to water pollution and sediments contamination in Serbian inland waters. Yet, ecotoxicological research, which should have been seen as a helping hand for the competent authorities, has been ignored for years and therefore remained isolated and restricted to small-scale laboratory and field monitoring, i.e. studies without or with very limited impact on environmental policy in general. Serbian scientific community has struggled, under extremely difficult conditions, to keep up with trends and progress in international research and development, by learning, adopting and applying ecotoxicological methods in locally relevant studies, which resulted with a certain number of publications, but more importantly, in valuable data easily applicable in water management and policy, once the relevant EU regulations, proper implementation strategies and environmental policy in general are fully transposed and incorporated into the Serbian legal system.

\section{Perspectives}

Modern approach to environmental risk assessment set forth by REACH and partly by the WFD, once fully transposed into national legal system, would certainly give additional stimulus to ecotoxicological research in Serbia. Research and institutional capacity building in Serbia should, hopefully, increase the competence and competitiveness of scientific community for participation in the EU FP and other large-scale research programmes and, on the other hand, contribute to radical changes in national environmental policy and management strategies. To catch up with trends in ecotoxicological research and risk assessment, the scientific community in Serbia should get prepared for new challenges-switching from descriptive 
and monitoring-like studies to fundamental and conceptual research on unresolved ecotoxicological issues and problems.

Acknowledgements This paper was originally presented at the $1 \mathrm{st}$ REP LECOTOX Workshop, 15-18 June 2008, in Novi Sad, Serbia (INCO-CT-2006-043559-REP-LECOTOX). I wish to express my gratitude to Walter Giger who kindly invited me to submit the paper to this issue. The critical reading of the earlier versions of the manuscript and comments of my colleagues, Radmila Kovačević, Ivana Ivančev-Tumbas and Jürg Bloesch is highly acknowledged. I thank Ms. Dubravka Bugarski Alimpić for the language editing that helped to improve the manuscript. Financial support of Ministry of Science and Technological Development, Republic of Serbia, Grant No. 143058 is also acknowledged.

\section{References}

Adamov J, Vojinović-Miloradov M, Buzarov D, Jovetić S, Sudji J, Popović E (2003) Distribution of PCBs at different levels of aquatic ecosystem in the Danube River in Vojvodina. Fresenius Environ Bull 12:117-120

Arambašić M, Bjelić S, Subakov G (1995) Acute toxicity of heavy metals (copper, lead, zinc), phenol and sodium on Allium cepa L., Lepidium sativum L. and Daphnia magna St.: comparative investigations and the practical applications. Water Res 29 (2):497-503

Borković S, Pavlović S, Kovačević T, Štajn A, Petrović V, Saičić Z (2008) Antioxidant defence enzyme activities in hepatopancreas, gills and muscle of Spiny cheek crayfish (Orconectes limosus) from the River Danube. Comp Biochem Physiol C 147:122-128

Brković-Popović I (1990) Effect of mercury on the survival of Daphnia magna. Water Sci Technol 22(5):241-246

Brković-Popović I, Popović M (1977a) Effects of heavy metals on survival and respiration rate of tubificid worms: part I. Effects on survival. Environ Pollut 13(1):65-72

Brković-Popović I, Popović M (1977b) Effects of the heavy metals on survival and respiration rate of tubificid worms: part II. Effects on respiration rate. Environ Pollut 13(1):93-98

Dalmacija B, Prica M, Ivančev-Tumbas I, van der Kooij A, Rončević S, Krčmar D, Bikit I, Teodorović I (2006) Pollution of the Begej Canal sediment - metals, radioactivity and toxicity assessment. Environ Int 32:606-615

ICPDR (2005) The Danube River Basin District. River basin characteristics, impact of human activities and economic analysis required under Article 5, Annex II and Annex III, and inventory of protected areas required under Article 6, Annex IV of the EU Water Framework Directive (2000/60/EC). Part A-basin-wide overview. ICPDR, Vienna

Ivančev-Tumbas I, Dalmacija B, Maljević E, Tričković J, Rončević S, Agbaba J. (2004): Sediment quality in Serbia - current state and the actions needed. In: 2nd European Conference on dredged sludge remediation, Amsterdam, The Netherlands

Ivančev-Tumbas I, Maljević E, Tamaš Z, Karlović E, Dalmacija B (2008) Organic micropollutants in the assessment of groundwater quality. Water Sci Technol Water Supply 7(3):155-162

Jovančević BS, Antić MP, Solević TM, Vrvić MM, Kronimus A, Schwarzbauer J (2005) Investigation of interactions between surface water and petroleum-type pollutants. Environ Sci Pollut Res 12(4):205-212

Kaišarević S, Andrić N, Bobić S, Tričković J, Teodorović I, Vojinović-Miloradov M, Kovačević RZ (2007) Detection of dioxin-like contaminants in soil from the area of oil refineries in Vojvodina Region of Serbia. Bull Environ Contam Toxicol 4 (79):422-426

Kaišarević S, Lubcke-von Varel U, Orčić D, Streck G, Sculze T, Pogrmić K, Teodorović I, Brack W, Kovačević R (2008) EDA of contaminated sediments. Case study: waste water canal flowing into Danube River from Pancevo (Serbia) industrial area. SETAC Europe 18th Annual Meeting, Warsaw, Poland, 25-29th May 2008, Abstracts Book, 138

Kallqvist T, Milačic R, Smital T, Thomas KV, Vraneš S, Tollefsen KE (2008) Chronic toxicity of the Sava River (SE Europe) sediments and river water to the algae Pseudokirchneriella subcapitata. Water Res 42:2146-2156

Karan V, Vitorović S, Tutundžic V, Poleksić V (1998) Functional enzymes activity and gill histology of carp after copper sulphate exposure and recovery. Ecotoxicol Environ Saf 40:49-55

Nešković NK, Elezović I, Karan V, Poleksić V, Budimir M (1993) Acute and subacute toxicity of atrazine to carp (Cyprinus carpio L.). Ecotoxicol Environ Saf 25(2):173-182

Nešković NK, Karan V, Elezović I, Poleksić V, Budimir M (1994) Toxic effects of 2, 4-D herbicide on fish. J Environ Sci Health Part B Pestic Food Contam Agric Wastes 29(2):265-279

Nešković NK, Poleksić V, Elezović I, Karan V, Budimir M (1996) Biochemical and histopathological effects of glyphosate on carp, Cyprinus carpio L. Bull Environ Contam Toxicol 56 (2):295-302

Planojević I, Bartova K, Bartoš T, Kaišarević S, Machat J, Blaha L, Teodorović I, Kovačević R (2008) Complex assessment of contaminated sediments: Case study Pancevo, Serbia, industrial wastewater canal. SETAC Europe 18th Annual Meeting, Warsaw, Poland, 25-29th May 2008, Abstract Book 139

Poleksić V, Jeremić S (2003) Effects of acute cyanide poisoning on the gills of fish. J Environ Prot Ecol 4(4):802-808

Poleksić V, Karan V (1999) Effects of trifluralin on carp: biochemical and histological evaluation. Ecotoxicol Environ Saf 43:213-221

Popović D, Todorović D, Frontasyeva M, Ajtić J, Tasić M, Rajšić S (2008) Radionuclides and heavy metals in Borovac, Southern Serbia. Environ Sci Pollut Res 15:509-520

Prica M, Dalmacija B, Rončević S, Krčmar D, Bečelić M (2008) A comparison of sediment quality results with acid volatile sulphide (AVS) and simultaneously extracted metals (SEM) ratio in Vojvodina (Serbia) sediments. Sci Total Environ 389:235-244

Radenković MB, Cupać SA, Joksić JD, Todorović DJ (2008) Depleted uranium mobility and fractionation in contaminated soil (southern Serbia). Environ Sci Pollut Res 15(1):61-67

Sakan S, Gržetić I, Đorđević D (2007) Distribution and fractionation of heavy metals in the Tisa (Tisza) River sediments. Environ Sci Pollut Res 14(4):229-236

Stanić B, Andrić N, Zorić S, Grubor-Lajšić G, Kovačević R (2006) Assessing pollution in the Danube River near Novi Sad (Serbia) using several biomarkers in sterlet (Acipenser ruthenus L.). Ecotoxicol Environ Saf 65:395-402

Stešević D, Feiler U, Sundić D, Mijović S, Erdinger L, Seiler T-B, Heininger P, Hollert H (2007) Application of a new sediment contact test with Myriophyllum aquaticum and of the aquatic Lemna test to assess the sediment quality of Lake Skadar. J Soils Sediments 7(5):342-349

SWRDMP (2002) The Republic of Serbia Water Resources Development Master Plan. Institute for the Development of Water Resources Jaroslav Cerni, Belgrade

Teodorović I, Planojević I (2008) Daphnia magna culturing methodsimplications on chronic toxicity tests. Fresenius Environ Bull 17 (8):985-991

Teodorović I, Đukić N, Maletin S, Miljanović B (2000) Metal Pollution Index - proposal for freshwater monitoring based on trace metal accumulation in fish. Tiscia 32:55-60 
Teodorović I, Bečelić M, Planojević I, Ivančev-Tumbas I, Dalmacija B (2009) The relationship between whole effluent toxicity (WET) and chemical-based effluent quality assessment in Vojvodina (Serbia). Environ Monit Assess (in press). doi:10.1007/s10661-008-0591-0

Terzić S, Senta I, Ahel M, Gros M, Petrović M, Barcel D, Müller J, Knepper T, Martí I, Ventura F, Jovančić P, Jabučar D (2008) Occurrence and fate of emerging wastewater contaminants in Western Balkan Region. Sci Total Environ 399(1-3):66-77

UNEP (2004) From conflict to sustainable development, assessment of environmental hot spots, Serbia and Montenegro. UNEP, Geneva

Vujošević M, Anđelković S, Savić G, Blagojević J (2008) Genotoxicity screening of the river Rasina in Serbia using the Allium anaphasetelophase test. Environ Monit Assess 147:75-81
Žikić RV, Štajn AS, Ognjanović BI, Pavlović SZ, Saicic ZS (1997) Activities of superoxide dismutase and catalase in erythrocytes and transaminases in the plasma of carps (Cyprinus carpio L.) exposed to cadmium. Physiol Res 46:391-396

Žikić RV, Štajn AS, Pavlović SZ, Ognjanović BI, Saičić ZS (2001) Activities of superoxide dismutase and catalase in erythrocytes and plasma transaminases of goldfish (Carassius auratus gibelio Bloch) exposed to cadmium. Physiol Res 50:105-111

Zorić S, Andrić N, Suđi J, Klanova J, Jovetić S, Kovačević R, Vojinović-Miloradov M (2004) Ethoxyresorufin-O-deethylase induction potency in sediment samples from rivers Lepenica and Morava-surrounding area of Kragujevac "hot spot". Organohalog Compd 66:598-602 